\title{
Integration of e-Learning for Mathematics on Resource- Based Learning: Increasing Mathematical Creative Thinking and Self-Confidence
}

\author{
https://doi.org/10.3991/ijet.v15i06.11915 \\ Poppy Yaniawati $\left.{ }^{(}\right)$ \\ Universitas Pasundan, Bandung, Indonesia \\ pyaniawati@unpas.ac.id \\ Rahayu Kariadinata \\ UIN Sunan Gunung Djati, Bandung, Indonesia \\ Nenden Mutiara Sari \\ Universitas Pasundan, Bandung, Indonesia \\ Euis Eka Pramiarsih \\ Universitas Langlang Buana, Bandung, Indonesia \\ Mira Mariani \\ SMPN 9 Sumedang, Sumedang, Indonesia
}

\begin{abstract}
The purpose of this study is to introduce the utilization of eLearning for mathematics on Resource-Based Learning (RBL) with a scientific approach to increase mathematical creative thinking ability and to develop students' self-confidence. This study is mixed-method research with classroom action research for its design. Data analysis is with one-way ANOVA for creative mathematical thinking ability, t-test for self- confidence survey, qualitative analysis for observation, and interviews on the self-confidence of grade VII junior high school students in Sumedang, Indonesia. The integration of e-learning into Resource-Based Learning method produced a better enhancement in mathematical creative thinking ability and self-confidence development compared to learning that does not implement e-learning. The scientific approach contributed to a positive influence on students' learning achievement. Creative mathematical thinking ability showed increases from one cycle - analysis of mathematical creative thinking ability covered aspects of fluency, flexibility, originality, and elaboration. The post-test result showed lower achievement in comparison to test results of the final learning cycle.
\end{abstract}

Keywords - Resources-based learning, E-learning, Mathematical creative thinking ability, Self-confidence, Junior high school, Scientific approach. 


\section{Introduction}

Mathematics learning most often is related to the process of non-routine problem solving and is not always relying on standard formulas. Complex mathematical problems usually require the ability to think creatively, which creates innovation in a variety of problem-solving. According to Ruggiero [1], creative thinking is a thinking method that produces various interpretations of the problem faced, accompanied by many ways to solve the problem and possibilities for solutions. Students with creative thinking ability are more likely to succeed in learning mathematics because they can develop their knowledge and capabilities to create various creative ways of problemsolving.

In addition to cognitive aspects, students' learning potential will grow when supported by ethical, affective aspects, particularly self-confidence. McPheat [2] stated that self-confidence is a person's belief that he or she can solve challenges, although the person never had prior experiences relating to those challenges. Self-confidence constitutes positive affective aspects that are necessary to establish beliefs about one's abilities. According to Kloosterman [3], motivation is an influence on students' successes and failures, self-confidence, and belief in their efforts. Galbraith and Haines in [4] stated that self-confident students possess the belief that they will be successful in their efforts, do not waver in facing delicate learning materials, always striving for best results, and mathematics for them is pleasant.

One of the many learning methods that can be used to create student activities that simultaneously enhance mathematical creative thinking and self-confidence is Resource-Based Learning (RBL). Campbell, in [5], stated that RBL is a learning model that engages students' activity in various learning using print and non-print resources. One of the strengths of this learning method is put forth by MacCrate and Carnegie in [6] that RBL can enhance students' abilities in practical problem-solving. Also, students have opportunities to build wide-ranging comprehension because they are not required to compile information that is the same for all students. The students are challenged to be active in collecting as much information as possible for independent scrutiny according to their capabilities. It is hoped that this will encourage students to learn according to the most suitable ways with their talents and abilities.

The teacher is not the sole source of learning. Students can learn in classrooms, laboratories, libraries, individual study rooms, or even out of school when they study the environment, related to specific problems or tasks. Nevertheless, RBL does not eradicate the teachers' role in monitoring the process of students' learning. The teacher is engaged in every step in the students' learning process, from planning, decision making, information collection, providing motivation, correcting mistakes, to assisting the students.

The spirit for renewal in raising the quality of education can be found in the RBL method as it is one of the strategies for the application of the constructivism paradigm. Suharwati in [7] states that the advantages of the RBL are:

- Enhancing motivation and learning ability

- Initiating new learning opportunities 
- Decreasing dependence on teachers

- Cultivating self-confidence in facing new challenges

- Continuous use of learning resources

- Enabling discovery of hidden talents in students.

Research of Ahmatika [8] found that RBL application through the scientific approach could build student's comprehension better. In the 2013 curriculum implementation, the scientific approach was directed to develop attitude, knowledge, and skills as substance transformation so that students know the "why," "how," and "what." In the 2013 curriculum, the scientific approach is designed with the purpose that students actively construct concepts, laws or principles, through the stages of observation, identification, and problem formulation, setting hypotheses, collection, and analyses of data, drawing inferences, and communication of the concept.

The scientific approach aims at giving comprehension to students in identifying and understanding various subjects through the scientific approach and discovering data using different techniques that are in line with the RBL concept. The application of the RBL method with the scientific approach is thus a learning experience based on various resources and implemented with scientific approaches where students are encouraged to observe, identify, formulate, analyze, draw inferences about results of their learning.

The ever-increasing progress of technology in all aspects of life has opened opportunities to meet the information technology requirements to support learning activities. Learning that is based on information technology, known as E-learning, is assured to contribute much to contemporary learning. Thus the learners' comprehension of learning mathematics can be accelerated through technology.

The application of e-learning can contribute benefits to the development of the RBL learning method with a scientific approach that is dominated by the need for information. Research by Ahmatika [8] found that the RBL method with a scientific approach can enhance students' mathematical creative thinking ability. Therefore, support from e-learning with high capacity to offer a broader source for learning will undoubtedly produce a better enhancement in mathematical creative thinking ability.

Based on the previous elaboration, this researcher team is encouraged to study the application of the RBL method with a scientific approach using e-learning media on efforts to enhance students' mathematical creative thinking and self-confidence. The purpose of this study to (1) analyze mathematical creative thinking ability and students' self-confidence by the RBL method with the scientific approach using elearning ; (2) to analyze correlations between mathematical creative thinking ability and students' self-confidence. 


\section{Theoretical Background}

\subsection{Resource-based-learning with e-learning}

In line with the fast-paced progress of information technology, the RBL with a scientific approach can also utilize e-learning as learning. It is assured that e-learning contributes much to contemporary learning. Advancement in technology that increases in all facts of life has opened opportunities for the fulfillment of the need for information technology means that will enhance students' mathematical abilities. That is in accord with Yaniawati, Kartasasmita, Kariadinata \& Sari [9], who stated that in this time of globalization, an acceleration in the process of learning mathematics is needed to develop mathematical abilities further; this is due to the fast growth of new information.

In this context, the learners' comprehension of mathematics learning will surely experience an acceleration through the role of technology. UNESCO in [10] stated that the integration of information and communication technology into learning has three objectives, i.e. for:

- The establishment of "knowledge-based society habits"

- The development of skills in the application of technology (ICT literacy)

- The enhancement of effectiveness and efficiency in the learning process

Polla [11] stated that the use of information technology implemented in the form of an e-learning-based system could be utilized to spur increased learning outcomes. The advantage of e-learning is that it has many and varied contents that can help the process of learning mathematics.

Application of information technology in learning mathematics can be observed in the appearance of e-learning that has specific characteristics. Clark \& Mayer [12] states that e-learning has characteristics, including:

- Having content that is relevant to the learning objectives

- Using instructional methods, for example, presenting examples and exercises to enhance learning

- Using media elements such as words and pictures to convey learning material

- Enable direct learning centered on the instructor or designed for independent learning

- Build understanding and skills related to learning objectives either individually or improve group learning performance.

According to Cute in [13], e-learning is the instructional content or learning experience resulting from, or supplied through, electronic media. Through e-learning, the learning process can be done interactively and becomes more appealing to enhance students' interest and spirit in learning. Thus, the RBL method with the scientific approach using e-learning media constitutes an innovative learning method that enables students to learn with a variety of resources, within a scientific frame and supported by interactive media based on information technology. 
The application of e-learning is beneficial for the development of the RBL method with a scientific approach that has a great need for information. Research by [8] found that the RBL method with a scientific approach can improve students' mathematical creative thinking ability. Thus, the existence of e-learning support that can provide broader learning resources can provide the improved ability of better mathematical creative thinking.

\subsection{The ability of creative thinking}

Munandar in [14] states that creative thinking is different thinking by giving various possibilities of correct answers or ways for an issue based on information provided with an emphasis on numbers and conformity. Creative thinking can be demonstrated through an attitude that implies perseverance, personal discipline, and attention. The activities involve mental activity such as asking questions, considering new information and unusual ideas with an open mind, linking each other freely, applying imagination, and pay attention to intuition. So, creative thinking is a mental activity associated with sensitivity to making the problem, considering further information and unusual ideas with an open mind, and making connections in solving the problem.

To find out the extent to which improvement of the ability of creative mathematical thinking obtained from the learning result, the researcher uses indicators referring to Munandar in [15], namely:

- Fluency

- Flexibility

- Originality

- Elaboration

Thus, the measurement of the ability of creative mathematical thinking in this research is focused on the assessment of the

- Fluency aspects, i.e., the ability to trigger many ideas, answers, problem-solving, or questions

- Flexibility is the ability to generate ideas, solutions, or questions that vary and change the way in approach by looking at the problem from different perspectives and alternatives

- Elaboration (ability) in developing an idea, adding or describing in detail an object, purpose, or situation encountered. Moreover

- Originality is the ability to express an opinion of itself in response to a problem faced.

\subsection{Self-confidence}

Confidence is one of the aspects of personality that can affect the learning process because confident students have confidence in their abilities and keep positive thinking, even when faced with a problem they have never met before. According to Kiverstein Rietveld, Slagter \& Denys [16], people are self-confident when they trust 
their abilities and surroundings. Self-confidence allows them to be open to the various possible actions that are relevant to them. Self-confidence is a construct that is going to be different and unique for each of us. Someone who appears to be full of selfconfidence might be quite different in reality [17].

\section{$3 \quad$ Method}

The research method used in this research is mixed methods that combine qualitative and quantitative approaches. The design of classroom action research for the study was through two particular treatment experiments to different groups and control groups. The experimental group consisted of the RBL with the Scientific Approach $\left(\mathrm{X}_{1}\right)$, called the experimental group-1, and the RBL with the Scientific Approach using the e-learning media $\left(\mathrm{X}_{2}\right)$, called the experimental group-2, while the group with conventional learning, called control group, as follows:

$\begin{array}{llll}\text { R: } & \text { O } & X_{1} & \text { O } \\ \text { R: } & \text { O } & X_{2} & \text { O } \\ \text { R: } & \text { O } & & \text { O }\end{array}$

Note:

R: Random

$\mathrm{O}$ : Pretest and post-test of mathematical creative thinking ability

$\mathrm{X}_{1}$ : $\quad$ Resource-Based Learning method with the scientific approach

$\mathrm{X}_{2}$ : Resource-Based Learning method with a scientific approach using e-

Learning

Classroom Action Research (CAR) is a classroom research activity carried out to solve learning problems faced by teachers, to improve the quality and learning outcomes and to try new things in learning for the sake of improving the quality and learning outcomes [18].

The study was conducted in SMPN 9 Sumedang with the following subjects:

- The experimental class 1, with the Resources-Based Learning model with the Scientific Approach

- The experimental class 2, with the Resources-Based Learning model with Scientific Approach using e-learning media

- The control class, with the conventional learning model. All three courses are taught by the same teacher, to avoid bias in the treatment.

The instruments used in this research were the test for creative thinking ability, questionnaire for self-confidence with Likert scale, a guide for observation, and interview. The data analysis used the One-way ANOVA. The study was conducted to determine whether or not there was a difference in the ability of mathematical creative thinking and self-confidence of students with the Resource-Based Learning model with Scientific Approach, the Resources-Based Learning model with Scientific Approach using e-learning and the conventional model. The better group was determined by the average value of statistics obtained in each learning group, i.e., the average of the results of the test of creative mathematical thinking ability and the average from 
the self-confidence questionnaire score based on the Likert scale. These instruments were subjected to a validation test. The tool for the examination of creative mathematical thinking covered tests for validity, reliability, level of difficulty, and distinguishing power. The self-confidence questionnaire has questions that include the validity and reliability tests.

The e-learning media used in this research is an application designed specifically for rectangles, GeoGebra applications, and Powerpoint presentations with animation, as shown in Figure 1.

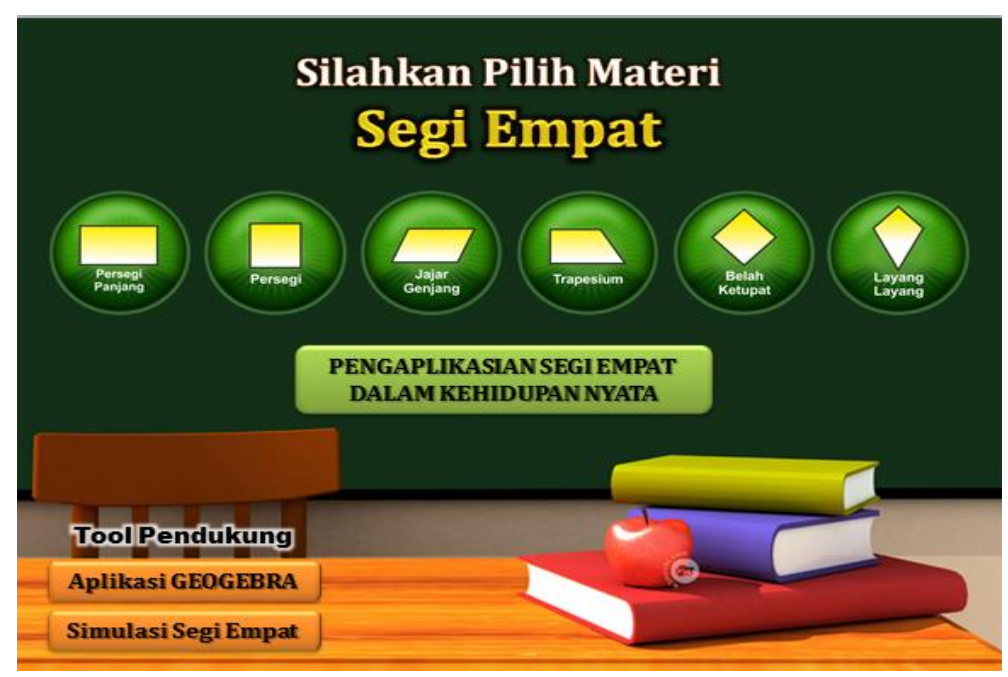

Fig. 1. Display E-learning Media

The particular application for rectangles is made for the students to perform the simulation of manufacture as well as the calculation of the circumference and the area of the various rectangular regions, as shown in Figure 2. 


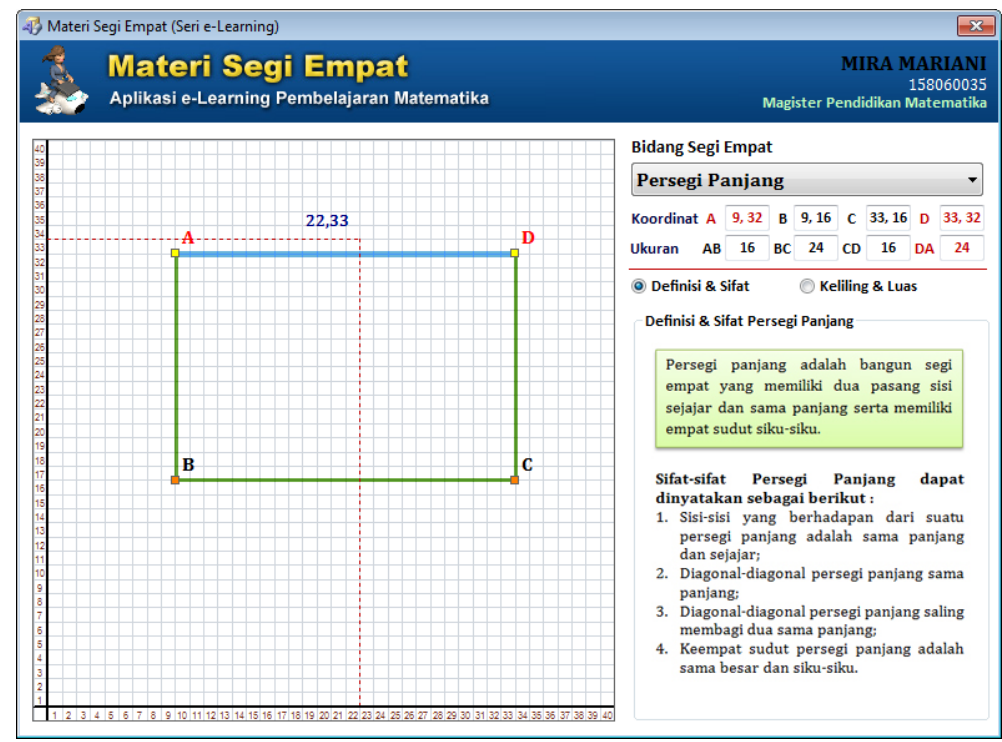

Fig. 2. Special Application of Rectangular Materials

Validity test on e-learning media is done through the Kendall Alignment Test based on five people assessment, consisting of three IT personnel and two experienced mathematics teachers. The result of significant value is $0.170>0.05$, meaning that the e-Learning application is acceptable and is aligned with each expert with an average score of 3.31 from a maximum value of 5 so that the e-Learning application is judged to have the right criteria.

\section{$4 \quad$ Results}

The results of the students' pretest on the creative mathematical thinking ability from each class showed the low results, viewed from fluency, skill, flexibility, originality, and elaboration of students in each learning group, can be seen in Table 1 below:

Table 1. Pretest Ability of Mathematical Creative Thinking

\begin{tabular}{|l|c|c|c|c|c|c|c|c|c|c|}
\hline & \multicolumn{4}{|c|}{ Statistic } & \multicolumn{4}{c|}{ Creative Thinking Ability } \\
\cline { 2 - 11 } & $\boldsymbol{N}$ & Avrg & SD & Min & Max & Fluen & Flexi & Org & Elab & Avrg \\
\hline RBL Scientific & 40 & 54,28 & 6,44 & 41,33 & 65,00 & 1,93 & 1,70 & 1,50 & 1,48 & 1,71 \\
\hline RBL Scientific e-Learning & 42 & 56,64 & 6,45 & 45,67 & 68,00 & 2,01 & 1,74 & 1,64 & 1,55 & 1,79 \\
\hline Conventional & 42 & 56,40 & 6,10 & 43,57 & 71,67 & 2,06 & 1,69 & 1,69 & 1,48 & 1,80 \\
\hline Total Average & & 55,77 & 6,33 & 43,52 & 68,22 & 2,00 & 1,71 & 1,61 & 1,50 & 1,77 \\
\hline
\end{tabular}

The result of hypothesis testing on the pretest of the mathematical creative thinking ability with one-way ANOVA method shows significance value of 0,186>0.05; thus, 
$\mathrm{H}_{0}$ is accepted; that is, there is no significant difference in the capacity of creative mathematical thinking in the experimental class or the control class. That indicates that the students' initial ability in each class is almost equal but is still low. Regarding creative thinking ability, students are also even less able in aspects of fluency, flexibility, originality, and elaboration in solving mathematical problems.

The result of statistical data processing of the posttest on the mathematical creative thinking ability of each class can be shown in Table 2 .

Table 2. Posttest Ability of Mathematical Creative Thinking

\begin{tabular}{|l|c|c|c|c|c|c|c|c|c|c|}
\hline \multirow{2}{*}{} & \multicolumn{4}{|c|}{ Statistic } & \multicolumn{4}{c|}{ Critical Thinking Ability } \\
\cline { 2 - 12 } & $\boldsymbol{N}$ & Avrg & SD & Min & Max & Fluen & Flexi & Org & Elab & Avrg \\
\hline RBL Scientific & 40 & 73,64 & 5,44 & 63,67 & 86,33 & 2,69 & 2,33 & 2,10 & 2,50 & 2,46 \\
\hline RBL Scientific e-Learning & 42 & 77,55 & 5,26 & 66,00 & 92,67 & 2,65 & 2,60 & 2,29 & 2,86 & 2,61 \\
\hline Conventional & 42 & 72,45 & 5,21 & 62,67 & 82,00 & 2,48 & 2,17 & 2,10 & 2,60 & 2,36 \\
\hline Total Average & & 74,55 & 5,30 & 64,11 & 87,00 & 2,61 & 2,37 & 2,16 & 2,65 & 2,48 \\
\hline
\end{tabular}

The result of hypothesis testing on the posttest of mathematical creative thinking ability with a one-way ANOVA method shows a significance value of $0.000<0.05$; thus $\mathrm{H}_{0}$ is rejected; that is, there is a significant difference in students' creative thinking ability among the three classes. That shows a significant difference where the highest results obtained by the RBL Scientific media e-learning class, followed by the RBL Scientific class, and the lowest is the conventional class. The learning outcome of the experimental class is better than the control class, where the class using the RBL method with Scientific Approach using e-learning media is better than the other classes.

From the aspect of creative thinking ability, it can be seen that the fluency, flexibility, originality, and students elaboration begin to increase the average value obtained. In this case, the best improvement is achieved by students in the RBL class with Scientific Approach using e-learning media, then the RBL class students with Scientific Approach and the lowest are students in the conventional class.

The N-gain scores from posttest and pretest results for the ability of student's mathematical creative thinking can be seen in table 3 .

Table 3. The gain of Mathematical Creative Thinking Ability

\begin{tabular}{|l|c|c|c|c|c|c|c|c|c|c|}
\hline & \multicolumn{4}{|c|}{ Average } & \multicolumn{4}{c|}{ Creative Thinking Ability } \\
\cline { 2 - 11 } & $\boldsymbol{N}$ & Pre & Pos & Gain & -Gain & Fluen & Flexi & Org & Elab & Avrg \\
\hline RBL Scientific & 40 & 54,28 & 73,64 & 19,36 & 0.42 & 0,76 & 0,63 & 0,60 & 1,03 & 0,75 \\
\hline RBL Scientific e-Learning & 42 & 56,64 & 77,55 & 20,90 & 0.48 & 0,64 & 0,86 & 0,64 & 1,31 & 0,82 \\
\hline Conventional & 42 & 56,40 & 72,45 & 16,06 & $0 . .37$ & 0,42 & 0,48 & 0,40 & 1,12 & 0,57 \\
\hline Total Average & & 55,77 & 74,55 & 18,77 & 0,45 & 0,61 & 0,66 & 0,55 & 1,15 & 0,71 \\
\hline
\end{tabular}

The N-Gain results of each class show a significant difference according to the one-way ANOVA test results where the significance value is $0.000<0.05$, and $\mathrm{H}_{0}$ is rejected. The RBL class students with Scientific Approach using e-learning media 
show the best N-gain, followed by RBL class students with Scientific Approach, and the lowest class is the conventional class students.

Graph 1. Pretest, cycle 1, cycle 2, cycle 3, and Posttest of Mathematical Creative Thinking

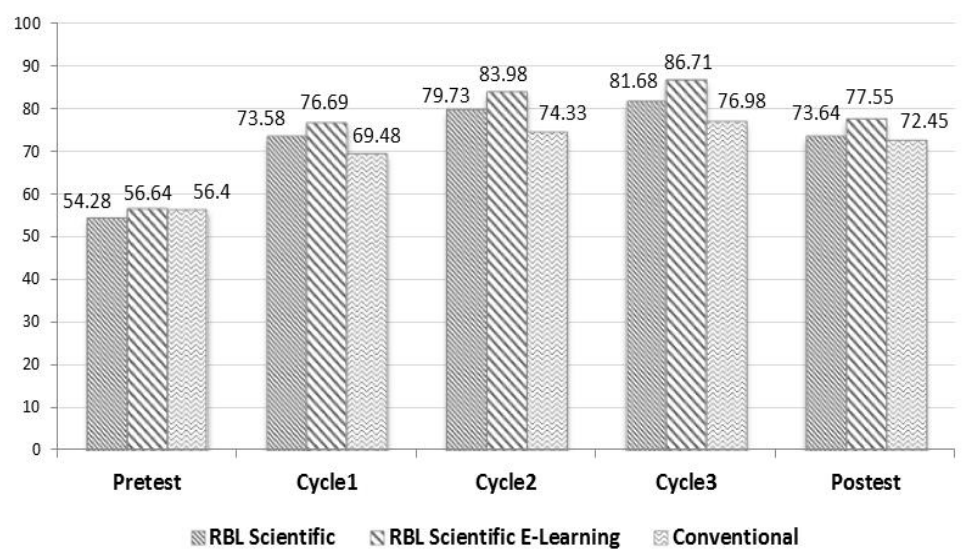

The students' mathematical creative thinking ability, which includes fluency, flexibility, originality, and elaboration aspects as a whole has improved, with the best result obtained by the RBL class with Scientific Approach using e-learning media followed by the RBL class with Scientific Approach and the conventional is the lowest. This is in line with the increasing ability of students in the RBL class with the Scientific Approach using e-learning media, which triggers many ideas to solve mathematical problems (fluency); provide many varied answers and have different perspectives and approaches (flexibility); solve issues in personal ways (originality) and provide details of an idea in solving mathematical problems (elaboration). Students in scientific learning place more emphasis on active, communicative, and collaborative activities [19].

In the fluency aspect, the best result is obtained by the RBL class with the Scientific Approach, followed by the RBL class with Scientific Approach using e-learning media, and the conventional class is the lowest. The increased ability of students in the RBL class with the Scientific Approach in sparking many ideas is influenced by the development of students' insights using many learning resources. Students in the RBL class also show similar conditions with the Scientific Approach using e-learning media that explains much insight from learning outcomes using many sources, including from the internet.

As for the flexibility, originality, and elaboration aspects, the most significant improvement of each RBL class is obtained by the Scientific Approach using e-learning media, followed by the RBL class with Scientific Approach, and the last is the conventional class. The student's ability in experimentation, especially of the RBL class with Scientific Approach using e-learning media, shows the capability of developing from different angles, detailing ideas and finding their way of solving problems, are indicators of the success of the RBL method with the Scientific Approach supported 
by the use of e-media -learning. In this case, the availability of various learning resources, including the support of information technology provides a significant influence on the development of students' ability to think and create in solving various mathematical problems.

Results of statistical data processing of student self-confidence measured by Likert scale is shown in the following table 4.

Table 4. The result of the Self-confidence Questionnaire

\begin{tabular}{|l|c|c|c|}
\hline \multirow{2}{*}{} & \multicolumn{3}{|c|}{ Class / Group } \\
\cline { 2 - 4 } & RBL Scientific & RBL Scientific e-learning & Conventional \\
\hline Average & 3,31 & 3,29 & 3,10 \\
\hline Standard Deviation & 0,3610 & 0,3536 & 0,3900 \\
\hline Minimum Value & 2,73 & 2,57 & 2,20 \\
\hline Maximum Value & 4,20 & 3,93 & 4,07 \\
\hline Total Score > 3 & 29 & 32 & 28 \\
\hline Total Objects & 40 & 42 & 42 \\
\hline
\end{tabular}

One-way ANOVA test result against self-confidence shows that the significance value of $0.015<0.05$; thus, $\mathrm{H}_{0}$ is rejected. That means that there are significant differences in the self-confidence of students in all three classes. The best selfconfidence students are in the RBL class with Scientific Approach using e-learning media followed by RBL class with Scientific Approach, and last is the conventional class. Table 5 presented assessment results on various aspects of the self-confidence of each class.

Table 5. Scores Related to Various Aspects of Self-confidence

\begin{tabular}{|l|c|c|c|}
\hline \multirow{2}{*}{\multicolumn{1}{|c|}{ Aspect }} & \multicolumn{3}{c|}{ Average Score of Class / Group } \\
\cline { 2 - 4 } & $\boldsymbol{R B L}$ Scientific & $\boldsymbol{R B L}$ Scientific e-learning & Conventional \\
\hline Maintain good self-image & 3,16 & 3,02 & 2,87 \\
\hline Think and act positively & 2,89 & 3,29 & 2,97 \\
\hline Mingling with others & 3,62 & 3,46 & 3,21 \\
\hline Act and speak confidently & 3,22 & 3,13 & 3,24 \\
\hline Help others wholeheartedly & 3,14 & 3,27 & 2,82 \\
\hline Active and enthusiastic & 3,70 & 3,44 & 3,35 \\
\hline
\end{tabular}

Based on table 5, RBL classes with Scientific Approach and RBL with a Scientific approach using e-learning media show that aspects of attitudes that include mingling with others, acting and speaking confidently, helping others wholeheartedly without expecting anything in return, and being active and enthusiastic have an average score of $>3$. In this case, the discussion and presentation activities carried out in the lesson show a positive impact on the realization of the development of various aspects of the attitudes. 


\section{$5 \quad$ Conclusion and Discussion}

In this paper, we introduce the e-learning mathematics utilization in ResourcesBased Learning (RBL) with a scientific approach, to improve the ability of mathematical creative thinking ability and develop the students' self-confidence. The result of this research shows that the improvement of mathematical creative thinking ability and self-confidence in each class differs significantly. In this case, the best development of the mathematical creative thinking ability and self-confidence occurred in the RBL group with Scientific Approach using e-learning media, followed by the RBL group with the Scientific Approach, and the last is the conventional learning group.

Conventional mathematics learning becomes an obstacle in realizing the independence and progressive nature of students who become supporting factors of improving the creative mathematics thinking ability and self-confidence. The tendency of mathematics teachers who dominate instruction resulted in low student activity, providing less opportunity to be directly involved in scientific activities. These conditions affect the limited opportunities for students to think creatively about their thoughts in finding new information or ideas from the learning process. This limitation must be avoided to optimize the ability of creative thinking that requires perseverance, personal discipline, and attention that involve mental activity, such as asking questions, considering new information, and unusual ideas with an open mind. In line with Beckman and Weber's findings [20], through e-learning, students often transmit outside knowledge into their discussions critically, although they often repeat information and post statements requiring further thought.

The paradigm of the teacher as a central figure in the class should be shifted to a facilitator who can direct the students to play an active role in learning. Teachers are not the only source of learning because students can seek or obtain learning materials from various sources both inside and outside the classroom. That is in line with Campbell's definition in [5], which states that Resource-Based learning is a learning model designed by instructors who actively engage students with a variety of learning resources, both print, and non-print. The condition is indeed different from the conventional learning where the teacher conveys the material on a limited basis, while the students do not have the opportunity to search for many other sources that can be utilized as a supporting reference.

On the other hand, the ability to think creatively will not develop without a positive attitude and mentality that support the creation of freedom of thought and creativity. It takes high confidence to get rid of doubts that hinder the nature of innovation and creativity. With the ability, skills, and belief, it is hoped that the difficulty in learning mathematics will be solved. Therefore, the ability to think creatively about learning mathematics and self-confidence become essential aspects' that need enhancement so that the learning of mathematics will produce better results.

About self-confidence, Foster [4] argues that students with high self-confidence believe that efforts can only produce good results, not afraid of challenging material, strive for excellent results, and being calm in facing lessons in mathematics. Conversely, students who lack confidence tend to feel nervous and consider themselves weak when facing mathematics lessons. 


\subsection{The mathematical creative thinking ability}

Improving the ability of creative mathematical thinking can be seen from the achievement of student's ability development before and after the application of learning methods. This is in line with the results of the studies by Khususwanto [21] and Ahmatika [8], which state that the improvement of students' mathematical creative thinking ability using the RBL method with Scientific Approach is better than conventional learning.

Improving the ability of creative mathematical thinking from learning outcomes shows that, in general, the fluency aspect has progressed where the students begin to be able to spark better ideas, answers, problem-solving, or questions. The RBL Method with Scientific Approach also improves the elaboration aspect because students are required to develop plans in detail in the learning process. Discussion and cooperation activities that are carried out in the RBL group with Scientific Approaches also enable students to improve the aspect of originality necessary to express opinions from a personal point of view. The use of e-learning media also positively influences the improvement of the ability of creative mathematical thinking. Technological advancements that have been growing have opened opportunities for the achievement of the availability of IT facilities that can support the improvement of students' mathematical skills.

In the RBL group with the Scientific Approach, students have the opportunity to build a broad understanding because they are not required to obtain the same information with other students. Students are required to be active in getting information as much as possible so that they study freely by the limits of their capabilities. It is expected to encourage students to learn in a way that best suits their talents and abilities.

The RBL Method with the Scientific Approach focuses on achieving students' ability to collect, identify, and observe information, hypothesize, compile questions, and process information and draw conclusions from problem-solving. With the achievement of the intended purpose, students will master the ability of creative mathematical thinking from aspects of fluency, flexibility, precision, and originality necessary to solve various problems and have the sensitivity to respond to various situations from their point of view.

Based on the observation of the researchers, it is found that the scientific approach can foster the students' activity in constructing concepts, laws, or principles through various stages. The stages are: observing, identifying, and formulating problems, setting hypotheses, collecting data with various techniques, analyzing data, drawing conclusions and communicating concepts, discovering the laws or principles. Thus, students understand that information might appear from anywhere and at any time, regardless of the teacher's online information. That is by the direction of the Ministry of Education and Culture [22], which states that learning conditions need to be directed to encourage students to discover from various sources through observation rather than just being notified. With the e-learning-based interactive media, students can better master the learning of mathematics because new audiovisual media support it and is more easily understood. Besides that, Kleitman, Sabina, and Stankov [23] argue, that e-learning teaching-learning methodology provides more flexibility and 
allows freedom from time, place, physical presence, hectic, and stressful teachinglearning, thus plays a vital role in the education system.

Application of the RBL method with the Scientific Approach integrated with elearning is a better form of learning innovation, where teacher's educative ability is combined with information technology advantage. Kariadinata and Yaniawati [24] report that learning by utilizing technology can improve students' thinking abilities. This research has novelty in the aspect of using an e-learning application that is optimized to support the learners' learning needs with various sources while developing the thinking power and creative thinking ability of the students through the practice of learning simulation. Besides, the research of Abou El-Scoud, Taj-Eddin, Seddiek, ElKhouly \& Nosseir [25] shows that the use of interactive e-learning features increases student motivation for the learning process.

According to the research by Yaniawati [13], students' mathematical ability gained through the application of blended learning (combination between e-learning model with conventional learning) is better than full e-learning and conventional models. In line with this, the RBL method with Scientific Approach using e-learning media can be a solution for the effort to improve mathematical creative thinking ability since it has the advantage of technical aspects and learning methods based on various sources, scientific, flexible and student-oriented as central learning figure, by actual conditions and needs.

\subsection{Self-confidence}

The development of self-confidence can be seen in the positive changes during the learning process. Based on observations of respondents, the researchers found that self-confidence in the learning group using the RBL method with the Scientific Approach is relatively better than the conventional learning group. This is similar to the study by Khususwanto [21] and Ahmatika [8], which stated that the students'selfconfidence using the Resources-Based Learning (RBL) method with Scientific Approach is better than students in conventional learning. Indicators of self-confidence can be seen in students who are characterized by respect for others, can build a sense of optimism, able to mingle and work together well, have the courage to act and speak, and more active in the learning process.

Conducting discussions and presentations that run conducive and full of activities is one key to success in building self-confidence in students. The occurrences of a two-way interaction between the teacher who acts as a facilitator and coordinator with students who have the opportunity to become central figures in the learning activities have an impact on the formation of self-confidence students. That can be explained given that the primary form of self-confidence is the interaction between students and teachers that are difficult to be found in conventional learning methods.

The use of IT facilities in the RBL group with the Scientific Approach using eLearning media will also provide a positive impact on students' self-confidence as the mastery of technology is the demand of life in the modern era. Students who already have the understanding and ability to use e-learning media will feel superior so that they will feel more confident. With all its advantages, e-learning media can provide 
beneficial support for the development of RBL methods with a Scientific Approach loaded with the information needs. Therefore, the RBL method with Scientific Approach using e-learning media would need to be developed further to become one of the new learning methods, which is interactive and easy to understand.

In the development of self-confidence aspect, teachers face challenges to the learning process, which not only focuses on the transfer of academic knowledge (hard skills) but also can teach values of attitude and character (soft skills). Thus, students can master hard skills and soft skills that will be integrated to form individuals who not only excel intellectually but also have emotional and spiritual intelligence. These individuals are reliable as agents of development for the future.

\subsection{Correlation between mathematical creative thinking ability and self- confidence}

This research found a correlation between students' mathematical creative thinking ability and self-confidence. The analysis found a tendency that the better the level of mathematical creative thinking ability, the higher is the self-confidence of the students. It makes sense, since the conditions in which a creative thinker is required to work with high skill, have a strong sense of confidence, and feel challenged to solve problems, be they relatively new and not well controlled. A person who can think creatively would have the confidence and belief in solving various problems with ideas and abilities. Conversely, self-confidence enables a person to improve the ability of creative mathematical thinking along with growth in spirit, motivation, and belief that all problems can be solved with passion and hard work to learn continuously to improve the abilities they possess. People who are more confident in one cognitive task tend to be more confident in other tasks [26].

Rahman [14] reported that students' self-concept about mathematics in Geogebraassisted learning might affect students' ability in creative mathematical thinking. In this case, the higher the self-concept as one of the associated aspects, with selfconfidence, the higher is the level of students' mathematical creative thinking ability. Also, the results of Herawati, Somatanaya, \& Hermanto's research [27] also showed that there was a relationship between self-confidence and students' mathematical creative thinking abilities using the Model-Eliciting Activities (MEAs). The results of the study indicate that overall indicators of self-confidence have a relationship with students' mathematical creative thinking abilities. The ability to think creatively is influenced by indicators that believe in one's abilities, act independently in making decisions, have positive self-concepts, and dare to express opinions.

Regarding self-confidence, Foster [4] argued that students with confidence have beliefs that effort can only obtain good results, not afraid of challenging material, excellent in getting good results, and being calm in handling lessons such as mathematics. Conversely, students who lack self-confidence tend to feel nervous and consider themselves inferior when facing math lessons.

Nevertheless, the correlation between self-confidence and various factors can influence mathematical creative thinking ability, such as students' ability to concentrate, students' socioeconomic status, and the ability of teachers to deliver subject material. 
If the multiple factors are in excellent condition, then self-confidence can be a trigger factor for students to release their potential and ability optimally.

In general, the results show a positive response from students for the RBL method with Scientific Approach using e-Learning media. In this case, students assume that the RBL method with Scientific Approach using e- Learning media provides a new learning experience where students have the opportunity to learn from multiple sources while utilizing various information technology features with all its advantages. As Costley [28] put forth that the number of lectures and media diversity both positively influence learning, satisfaction, engagement, interest (LSE), then media diversity is useful for online learning.

\section{Acknowledgement}

This study was supported by Universitas Pasundan, and thanks to Mr. Bana G. Kartasasmita, Ph.D for reviewing the language of the article.

\section{$7 \quad$ References}

[1] R.V. Ruggiero, The art of thinking. A guide to critical and creative thought. Tenth edition. New York: Longman, an Imprint of Addison Wesley Longman, Inc, 2013.

[2] S. McPheat, Personal confidence, and motivation. London: MTD Training \& Ventus Publishing APS, 2010.

[3] S. Nurqolbiah, "Peningkatan kemampuan pemecahan masalah, berpikir kreatif dan selfconfidence siswa melalui model pembelajaran berbasis masalah," Jurnal Penelitian Pendidikan dan Pengajaran Matematika, vol. 1 no. 3, pp. 225-240, 2016. [Online serial]. Available: http://jurnal.unsil.ac.id/index.php/jp3m/article/view/166 https://doi.org/10.30 870/jppm.v10i2.2025

[4] C. Foster, "Confidence and competence with mathematical procedures," Educational Studies in Mathematics, vol. 91, no. 2, pp. 271-288, 2016. [Online serial]. Available: https:// link.springer.com/article/10.1007/S10649-015-9660-9

[5] U. H. Aliyah, H. Suyitno and A. Agoestanto, "Keefektifan resource-based learning terhadap kemampuan pemecahan masalah peserta didik materi lingkaran," Jurnal Pendidikan Matematika dan Sains, vol. 2, no. 1, pp. 10-18, 2014. [Online serial]. Available: https:// journal.uny.ac.id/index.php/ipms/article/view/3888 https://doi.org/10.24853/fbc.2.1.23-30

[6] M. Butler, "Resource-based learning and course design," Law Library Journal, No. 201124, 2012.

[7] I.M. Qoyum, et al, "Pengaruh pendekatan resource based learning dikombinasikan scramble terhadap hasil belajar siswa," presented at the Seminar Nasional Pendidikan Membangun Generasi Berpendidikan dan Religius Menuju Indonesia Berkemajuan, 2016, pp. 66-72. https://doi.org/10.30821/ansiru.v3i2.5847.s825

[8] D. Ahmatika, "Peningkatan kemampuan berpikir kreatif matematis dan self-confidence siswa smp melalui resources-based learning rbl dengan pendekatan scientific : penelitian kuasi eksperimen terhadap siswa kelas vii salah satu SMPN,” Tesis. Unpublished, Universitas Pendidikan Indonesia, Bandung, 2015. [Online serial]. Available: http://rep ository.upi.edu/17502/ https://doi.org/10.23969/literasi.v7i2.511 
[9] R.P. Yaniawati, B.G. Kartasasmita, R. Kariadinata \& E. Sari, “Accelerated learning method using edmodoto increase students' mathematical connection and self-regulated learning," presented at the International Conference on Education and Multimedia, Singapore, 2017, pp. 53-57. https://doi.org/10.1145/3124116.3124128

[10] P. Yuliatmojo, "Mempersiapkan guru pada strategi pembelajaran berbasis teknologi informasi dan komunikasi," presented at the Seminar Internasional Peran LPTK dalam Pengembangan Pendidikan Vokasi di Indonesia, 2012, pp. 495-500. https://doi.org/10.24 114/jtikp.v1i1.1873

[11] G. Polla, "Peranan Teknologi Informasi dalam Pengembangan E-Learning pada Fakultas Mipa di Indonesia," ComTech: Computer, Mathematics and Engineering Applications, vol. 1, no. 2, pp. 1025-1032, 2010. https://journal.binus.ac.id/index.php/comtech/article/view/ 2659 https://doi.org/10.21512/comtech.v1i2.2659

[12] R.C. Clark \& R.E. Mayer, "Elearning, and the science of instruction: proven guidelines for consumers and designers of multimedia learning", second edition. San Francisco: John Wiley \& Sons, Inc, 2018. https://doi.org/10.1002/9781118255971

[13] R.P. Yaniawati, "E-Learning to improve higher order thinking skills hots of students," Journal of Education and Learning, vol 7, no. 2, pp. 109-120, 2013. [Online serial]. Available: https://www.neliti.com/publications/72339/e-learning-to-improve-higher-order-think ing-skills-hots-of-students https://doi.org/10.11591/edulearn.v7i2.225

[14] R. Rahman, "Hubungan antara self-concep terhadap matematika dengan kemampuan berpikir kreatif matematik siswa," Infinity Journal, vol 1, no. 1, pp. 19-30, 2012. [Online serial]. Available: http://www.e-journal.stkipsiliwangi.ac.id/index.php/infinity/article/view/4 https://doi.org/10.22460/infinity.v1i1.4

[15] A. Jazuli, "Berpikir kreatif dalam kemampuan komunikasi matematika," presented at the Seminar Nasional Matematika dan Pendidikan Matematika Jurusan Pendidikan Matematika FMIPA UNY, 2009, pp. 209-220. https://doi.org/10.33603/jnpm.v3i1.1466

[16] J. Kiverstein, E. Rietveld, H. A. Slagter and D. Denys, "Obsessive compulsive disorder: A pathology of self-confidence?" Trends in cognitive sciences, vol. 23, no. 5, pp. 369-372, 2019. [Online serial]. Available: https://www.sciencedirect.com/science/article/pii/S13646 61319300609 https://doi.org/10.1016/j.tics.2019.02.005

[17] R. Hughes, A. Kinder, \& C. L. Cooper, "Developing Self-confidence." The Wellbeing Workout. Palgrave Macmillan, Cham, pp. 285-289, 2019. [Online serial]. Available: https://link.springer.com/chapter/10.1007/978-3-319-92552-3_48 https://doi.org/10.1007/ 978-3-319-92552-3_48

[18] A. Widayati, "Penelitian tindakan kelas." Jurnal Pendidikan Akuntansi Indonesia, vol. 6, no. 1, pp. 87-93, 2008. [Online serial]. Available: https://journal.uny.ac.id/index.php/jpa kun/article/view/1793/1487 https://doi.org/10.21831/jpai.v6i1.1793

[19] R. M. Sari, S. Sumarmi, I. K. Astina, D. H. Utomo, \& R. Ridhwan, "Measuring students scientific learning perception and critical thinking skill using paper-based testing: school and gender differences," International Journal of Emerging Technologies in Learning, vol. 14, no. 19, pp. 132-149, 2019. [Online serial]. Available: https://online-journals.org/index. php/i-jet/article/view/10968/5969 https://doi.org/10.3991/ijet.v14i19.10968

[20] J. Beckmann and P. Weber, "Cognitive presence in virtual collaborative learning, Assessing and improving critical thinking in online discussion forums," Interactive Technology and Smart Education, vol 13, no 1, pp. 52-70, 2016. [Online serial]. Available: https://www.emerald.com/insight/content/doi/10.1108/ITSE-12-2015-0034/full/html https ://doi.org/10.1108/itse-12-2015-0034

[21] Khususwanto, "Pembelajaran matematika dengan pendekatan resource- based learning untuk meningkatkan kemampuan berpikir kreatif matematis dan self-confidence siswa SMP," 
Tesis. Unpublished, Universitas Pendidikan Indonesia, Bandung, 2013. [Online serial]. Available: http://repository.upi.edu/2142/ https://doi.org/10.26594/jmpm.v1i1.513

[22] Kementerian Pendidikan dan Kebudayaan, Peraturan menteri pendidikan dan kebudayaan nomor 20 tahun 2016 tentang tentang standar kompetensi lulusan pendidikan dasar dan menengah. Jakarta. Kemendikbud, 2016. https://doi.org/10.31219/osf.io/gepqc

[23] R. Kariadinata, and R. P. Yaniawati, "The implementation of GeoGebra software-assited DDFC instructional model for improving students' Van-Hiele geometry thinking skll," presented at the International Conference on Education and Multimedia Technology, 2017, pp. 58-62. https://doi.org/10.1145/3124116.3124129

[24] S. Kleitman, and L. Stankov, "Self-confidence and metacognitive processes," Learning and individual differences, vol. 17, no. 2, pp. 161-173, 2007. [Online serial]. Available: https://www.sciencedirect.com/science/article/pii/S1041608007000349 https://doi.org/10. 1016/j.lindif.2007.03.004

[25] M. S. Abou El-Seoud, I. A .Taj-Eddin, N. Seddiek, M. M. El-Khouly, \& A. Nosseir, "Elearning and students' motivation: a research study on the effect of e-learning on higher education," International Journal of Emerging Technologies in Learning, vol. 9, no. 4, pp. 20-26, 2014. [Online serial]. Available: https://online-journals.org/index.php/i-jet/article/ view/3465/3211 https://doi.org/10.3991/ijet.v9i4.3465

[26] Q. N. Naveed, A. Muhammed, S. Sanober, M. R. N. Qureshi and A. Shah, "Barriers effecting successful implementation of e-learning in Saudi Arabian Universities," International Journal of Emerging Technologies in Learning, vol. 12, no. 6, 2017. [Online serial]. Available: https://online-journals.org/index.php/i-jet/article/view/7003/4476 https://doi.org/10. 3991/ijet.v12i06.7003

[27] E. Herawati, A. A. G. Somatanaya and R. Hermanto, "Hubungan self-confidence dan kemampuan berpikir kreatif matematik peserta didik yang diajar menggunakan model elicting activities (MEAs)," Journal of Authentic Research on Mathematics Eduacation (JARME), vol. 1, no. 1, 2019. http://jurnal.unsil.ac.id/index.php/jarme/article/view/621

[28] J. Costley and C. H. Lange, "Video lectures in e-learning: effects of viewership and media diversity on learning, satisfaction, engagement, interest, and future behavioral intention," Interactive Technology and Smart Education, vol. 14, no. 1, pp. 14-30, 2017. [Online serial]. Available: https://www.emerald.com/insight/content/doi/10.1108/ITSE-082016-0025/full/html https://doi.org/10.1108/itse-08-2016-0025

\section{Authors}

Poppy Yaniawati is a professor at Universitas Pasundan. She received her Doctorate in mathematics education from the Universitas Pendidikan Indonesia. Poppy teaches courses the application of technology, research metodology and research statistic in the master's program. In addition, she is a reviewer of an accredited and internationally reputed journal.

Rahayu Kariadinata is a professor at UIN Sunan Gunung Djati. She received her Doctorate in mathematics education from the Universitas Pendidikan Indonesia. Rahayu teaches courses the multimedia mathematics learning, learning evaluation, and research methods. in Faculty of Tarbiyah and Teacher Training.

Nenden Mutiara Sari is a lecturer at Universitas. She received her Doctorate in mathematics education at the Universitas Pendidikan Indonesia. Nenden teaches courses application of technology and research statistics in the master's program. 
Euis Eka Pramiarsih is a lecturer at Universitas Langlang Buana. She received her Doctorate in Economics at Universitas Hasanuddin Makassar. Euis teaches courses the integrated marketing application, marketing management, financial management.

Mira Mariani is a mathematics teacher at SMPN 9 Sumedang, Indonesia. She obtained a master's degree in mathematics education from Universitas Pasundan.

Article submitted 2019-10-21. Resubmitted 2019-11-11. Final acceptance 2019-12-20. Final version published as submitted by the authors. 